Tropical Journal of Pharmaceutical Research October 2020; 19 (10): 2055-2060

ISSN: $1596-5996$ (print); 1596-9827 (electronic) (C) Pharmacotherapy Group, Faculty of Pharmacy, University of Benin, Benin City, 300001 Nigeria.

\title{
Dihydropyrano[2,3-c]pyrazole-induced apoptosis in lung cancer cells is associated with ROS generation and activation of $\mathrm{p} 38 / \mathrm{JNK}$ pathway
}

\author{
Miao He, Chao Li, Yingying He, Guangquan Yang, Youcai Zhang, Zhaohong \\ Chen* \\ Department of Oncology, People's Hospital of Deyang City, Deyang 618000, Sichuan, China
}

*For correspondence: Tel/Fax: +86 838220 1917; Email: hbmlup@163.com

Sent for review: 9 April 2020

Revised accepted: 27 September 2020

\begin{abstract}
Purpose: To investigate the effect of 2,4-dihydropyrano[2,3-c]pyrazole (DHPP) on lung cancer cells, and the associated mechanism.

Methods: The effect of DHPP on cell proliferation was measured using sulphorhodamine B (SRB) assay. Apoptosis of cells was determined using Olympus IX71 inverted microscope connected to FITC and rhodamine filters.

Results: DHPP significantly suppressed the proliferation of A549 and H1299 cells at doses of 0.5-8.0 $\mu M$, but did not affect normal cells (MRC5 and BEAS-2B). In DHPP-treated A549 and H1299 cells, caspase-3 activity was markedly enhanced. At $24 \mathrm{~h}$ of treatment with $8.0 \mu M$ DUPP, apoptosis in A549 and H1299 cells was increased to 67.89 and $61.35 \%$, respectively. Phosphorylation levels of JNK-1/2 and p38 in DHPP-treated A549 and H1299 cells were markedly enhanced. The p-ERK-1/2 expressions in DHPP-treated A549 and H1299 cells were suppressed significantly at $24 \mathrm{~h}$. In DHPP-treated A549 and H1299 cells, DCF-fluorescence was increased 10 folds and 8.5 folds, respectively. Pretreatment with FeTMPyP, an antioxidant, effectively alleviated DHPP-induced increase in expressions of p-p38 and $p$-JNK, and suppression of expression of $p$-ERK-1/2. In FeTMPyP-pre-treated cells, the DHPPinduced increase in caspase-3 activity was markedly reduced.

Conclusion: DHPP selectively inhibits lung cancer cell growth via oxidative stress which subsequently causes cell apoptosis. Moreover, it activates caspase-3 protein and p38/JNK signaling, with simultaneous inactivation of ERK-1/2. Therefore, DHPP has a potential to be developed for the treatment of lung cancer. However; more studies are required to confirm these findings.
\end{abstract}

Keywords: Lung cancer, Anti-oxidant, Apoptosis, Caspase-3, Chemotherapy

\begin{abstract}
This is an Open Access article that uses a funding model which does not charge readers or their institutions for access and distributed under the terms of the Creative Commons Attribution License (http://creativecommons.org/licenses/by/4.0) and the Budapest Open Access Initiative (http://www.budapestopenaccessinitiative.org/read), which permit unrestricted use, distribution, and reproduction in any medium, provided the original work is properly credited.
\end{abstract}

Tropical Journal of Pharmaceutical Research is indexed by Science Citation Index (SciSearch), Scopus, International Pharmaceutical Abstract, Chemical Abstracts, Embase, Index Copernicus, EBSCO, African Index Medicus, JournalSeek, Journal Citation Reports/Science Edition, Directory of Open Access Journals (DOAJ), African Journal Online, Bioline International, Open-J-Gate and Pharmacy Abstracts

\section{INTRODUCTION}

Lung cancer is the most common cause of mortality associated with cancers, and it has very high metastatic potential [1]. Causative molecular mechanistic studies have very effectively helped in development of treatment strategies for lung cancer, as well as improvements in patient prognosis [2]. However, despite improved treatment 
strategies, the 5-year survival of lung cancer patients is only $17 \%$ [3]. Therefore, further mechanistic investigations and search for effective therapeutic compounds are required for pulmonary cancer treatment.

Reactive oxygen species (ROS), the bye products generated during various metabolic processes, have either beneficial or toxic effects [4]. Abnormally increased ROS levels initiate oxidative stress leading to activation of secondary events like apoptotic, autophagic and necrotic cell death [5]. The ROS-induced stress activates mitogen-activated protein kinase (MAPK) comprising extracellular signal-related kinases (ERKs), c-Jun $\mathrm{NH}_{2}$-terminal kinases (JNKs) and p38 MAPKs at cellular level [6]. Oxidative stress-mediated cellular apoptosis is linked to phosphorylation of p38 and JNK proteins [7]. The vital roles of MAPKs have been clearly demonstrated in multiple cellular processes such as proliferation and apoptosis [8]. Many anticancer drugs rely on apoptosis activation to eliminate cancerous cells [9].

Heterocyclic molecules bearing pyrazole rings connected to pyrans possess diverse pharmacological properties. For example, compounds such as 1,4- and 2,4dihydropyrano[2,3c]pyrazoles exhibit significant anticancer [10] and anti-inflammatory effects [11]. Studies have shown that the substituted 2 Hfuro[2,3-c]pyrazoles possess anti-platelet and anti-allergic properties [12,13]. The present study investigated the anti-proliferative effect of 2,4-dihydropyrano[2,3-c]pyrazole (Figure 1) on lung cancer cells, and the underlying mechanism.<smiles>Cc1cc(Br)cc(C)c1Oc1cc(Nc2ccc(C#N)cc2)c(N)cc1N</smiles>

Figure 1: Chemical structure of 2,4-dihydropyrano[2,3c]pyrazole

\section{EXPERIMENTAL}

\section{Cell culture}

The A549 and H1299 cancer cells and normal cells (BEAS-2B and MRC-5 cell lines) were obtained from ATCC, USA. The cell lines were grown in DMEM containing $10 \%$ FBS and the antibiotics penicillin and streptomycin, each at a concentration of $100 \mathrm{U} / \mathrm{mL}$. The cells were grown overnight under humidified atmosphere containing $5 \% \mathrm{CO}_{2}$ in an incubator at $37^{\circ} \mathrm{C}$.

\section{Cytotoxicity assay}

Changes in cell proliferation due to treatment with DHPP at doses of 0.5, 1.0, 2.0, 4.0 and 8.0 $\mu \mathrm{M}$ DHPP were measured using SRB assay [17]. Cells in DMEM in 24-well plates at $90 \%$ confluence were treated with DHPP for $24 \mathrm{~h}$. Thereafter, the cells were fixed for $1 \mathrm{~h}$ with $30 \%$ trichloroacetic acid at $4{ }^{\circ} \mathrm{C}$ and rinsed with deionized water, followed by air-drying at room temperature. Then, the cells were incubated at room temperature with SRB $(0.04 \%)$ for $40 \mathrm{~min}$, after which they were washed thrice in $1 \%$ acetic acid, air-dried and put in Tris-base $(10 \mathrm{mM})$. The absorbance of the cells was read at $568 \mathrm{~nm}$ using EnSpire multimode plate reader.

\section{Assay of caspase-3 activity}

Cells pretreated with MAP kinase inhibitor for $1 \mathrm{~h}$ were exposed to $8.0 \mu \mathrm{M}$ DHPP for $24 \mathrm{~h}$, and caspase-3 activation was determined using AFCconjugated tetrapeptide substrates. Termination of incubation was followed by PBS washing and lysis with ice-cold buffer (50 mM HEPES, pH 7.4, containing $5 \mathrm{mM}$ CHAPS and $5 \mathrm{mM}$ DTT). The lysate was centrifuged at $4{ }^{\circ} \mathrm{C}$ for $15 \mathrm{~min}$ at $12,000 \mathrm{~g}$ and the supernatant was mixed with assay buffer [HEPES (40 mM), pH 7.4, containing CHAPS (0.2 \%), EDTA (4 mM) and DTT $(10 \mathrm{mM})$ ] and caspase-3 substrate $(40 \mathrm{nM}$ Ac-DEVD-7AFC). The mixture was incubated at $37{ }^{\circ} \mathrm{C}$, and fluorescence was measured after 5 min using multimode plate reader (Perkin Elmer).

\section{Annexin-V/FITC staining}

The cells were cultured on coverslips of 6-well plates and exposed for $24 \mathrm{~h}$ to $8.0 \mu \mathrm{M}$ DHPP. After washing the cover-slips in PBS, the cells were treated with $1 \mathrm{X}$-binding buffer and subsequently stained using Annexin-V/FITC antibodies for $40 \mathrm{~min}$ in the dark. Thereafter, the cells were treated with $1 \mathrm{X}$ binding buffer as per protocol of the manufacturer (Clontech Inc, USA). The cells were fixed in $2 \%$ formaldehyde prior to monitoring of fluorescence using OlympusIX71inverted microscope connected to FITC and rhodamine filters.

\section{Measurement of ROS production}

Abnormally high production of ROS was measured in cells using carboxy-H2-DCFDA (molecular Probes [14]. Termination of cellular incubation in 12-well plates was followed by 
aspiration of the medium and subsequent cell washing with PBS. Serum-free DMEM was added to $10 \mathrm{mM}$ carboxy-H2-DCFDA and incubation was carried out for $25 \mathrm{~min}$ at $37^{\circ} \mathrm{C}$. Then, the cells were washed with PBS and fluorescence measurement was done using OlympusIX71 inverted microscope connected to FITC filters.

\section{Western blot assay}

Cells treated with $8.0 \mu \mathrm{M}$ DHPP were rinsed with PBS and subjected to centrifugation for $5 \mathrm{~min}$ at $450 \mathrm{~g}$. The cells were re-suspended in RIPA (100 $\mathrm{mL}$ ) containing protease inhibitors and $10 \mathrm{mM}$ sodium ortho-vanadate (Sigma). The lysates were centrifuged at $13000 \mathrm{~g}$ for $15 \mathrm{~min}$ at $4^{\circ} \mathrm{C}$, and their protein levels were estimation using Bradford's method. Thereafter, $25 \mathrm{mg}$ protein samples were subjected to $10 \%$ SDS-PAGE and subsequently transferred to PVDF membranes. Protein probing was made by incubation overnight at $4{ }^{\circ} \mathrm{C}$ with primary antibodies against p-ERK-1/2, p-p38, p-JNK, a-tubulin, ERK-1/2, p38 and JNK (Cell Signaling Technology). This was followed by washing and $1 \mathrm{~h}$ incubation with anti-rabbit Ig-G-conjugated secondary antibody (Sigma-Aldrich) at room temperature. Band development was made using ECL Prime blotting reagent (GE, Life Sciences). The intensities of the bands were calculated with GeneTools software.

\section{Statistical analysis}

Data are expressed as mean \pm S.D. Differences were determined statistically using one-way analysis of variance (ANOVA). The data was analyzed using GraphPad Prism 5 software (GraphPad, San Diego, CA, USA). Differences were taken as significant at $p<0.05$.

\section{RESULTS}

\section{DHPP decreased viability of lung cancer cells}

The anti-proliferative potential of DHPP against cancer cells (A549 and H1299) and normal cells (MRC5 and BEAS-2B) are shown in Figure 2. The cells were exposed to increasing doses of DHPP $(0.5,1.0,2.0,4.0$ and $8.0 \mu \mathrm{M})$ for $24 \mathrm{~h}$. The toxicity of DHPP was more prominent against A549 cells than H1299 cells. Treatment with $8.0 \mu \mathrm{M}$ DHPP decreased the viabilities of A549 and H1299 cell lines to 23 and $29 \%$, respectively. However, DHPP did not induce significant toxicity in MRC5 and BEAS-2B cell cultures at the tested concentration range $(0.5$ $8.0 \mu \mathrm{M})$.

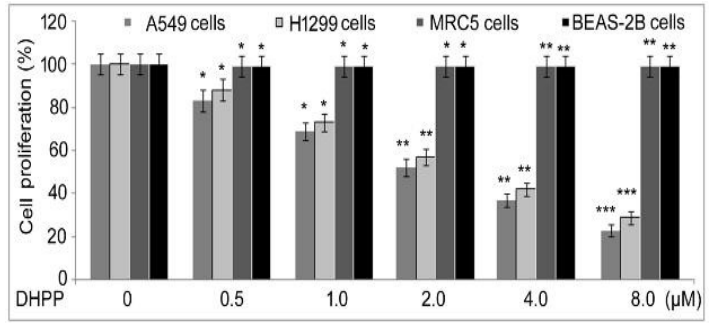

Figure 2: Effect of DHPP on the viabilities of normal and lung cancer cells. Normal cell lines (MRC5 and BEAS-2B) and cancer cell lines (A549 and H1299) were incubated with DHPP for $24 \mathrm{~h}$ and analyzed using SRB assay. ${ }^{*} p<0.0487,{ }^{* *} p<0.0198,{ }^{* * *} p<$ 0.0099 , vs. control cells

\section{Induction of cell apoptosis in lung cancer cells by DHPP}

The effect of $24 \mathrm{~h}$ treatment with DHPP on caspase-3 activities in A549 and H1299 cells is shown in Figure $3 \mathrm{~A}$. The DHPP treatment promoted caspase-3 activities in A549 and $\mathrm{H} 1299$ cells in a dose-dependent manner. Moreover, DHPP enhanced apoptosis of A549 and H1299 cells (Figure 3 B). At $24 \mathrm{~h}$ of treatment with DHPP $(8.0 \mu \mathrm{M})$, apoptosis in A549 and $\mathrm{H} 1299$ cells increased to 67.89 and $61.35 \%$, respectively.
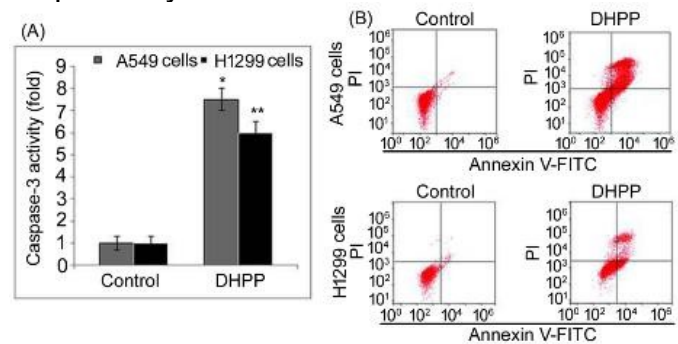

Figure 3: Effect of DHPP on cellular apoptosis. (A) Caspase-3 expressions in A549 and $\mathrm{H} 1299$ cells after $24 \mathrm{~h}$ of incubation with DHPP, as assayed with western blotting. (B) Apoptosis in control and $8.0 \mu \mathrm{M}$ DHPP-treated cells, as analyzed using AnnexinV/FITC and PI staining, and fluorescence. ${ }^{*} p<0.0187$, ${ }^{* *} p<0.0099$, vs. control cells

\section{DHPP promoted p38/JNK pathway activation}

Figure 4 shows the effect of DHPP on ERK, p38 and JNK activation in A549 and H1299 cells after $24 \mathrm{~h}$. There were marked increases in p38phosphorylation in DHPP-treated A549 and H1299 cells, relative to control. The $24 \mathrm{~h}$ DHPP treatment also significantly elevated p-JNK-1/2 expressions in A549 and H1299 cells, but suppressed $\mathrm{p}-\mathrm{ERK}-1 / 2$ expressions in these cells. Pre-treatment of A549 and $\mathrm{H} 1299$ cells with PD169316 (p38 inhibitor) or SP600125 (JNK inhibitor) significantly reversed DHPP-induced promotion of caspase-3 activity. However, U0126 
(MEK inhibitor) pretreatment did not suppress the DHPP-induced promotion of caspase-3 activities in A549 and H1299 cells.

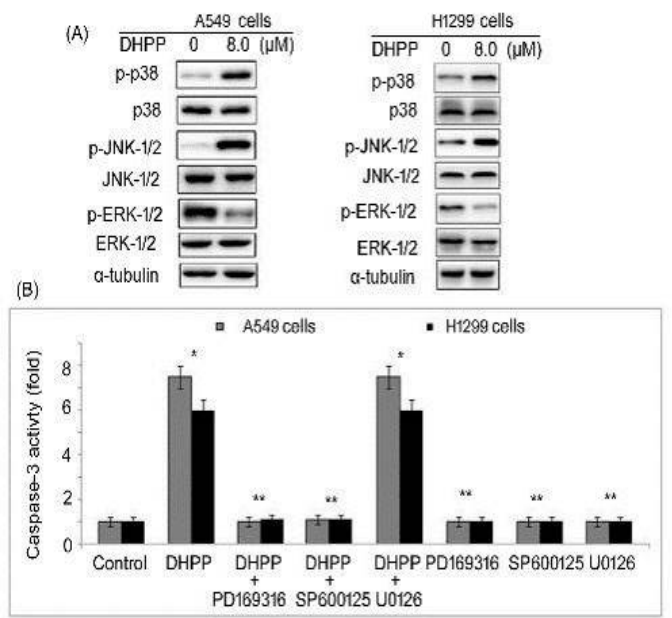

Figure 4: Effect of DHPP on p38/JNK activation. (A) The $8.0 \mu \mathrm{M}$ DHPP treated or control cells were analyzed for changes in ERK, p38 and JNK activation at $24 \mathrm{~h}$ using western blotting. (B) Pre-treatment with p38/JNK/MEK inhibitors, each at a dose of $5 \mathrm{mM}$ for 1 $\mathrm{h}$, and subsequent incubation with $8.0 \mu \mathrm{M}$ DHPP was followed by caspase- 3 activation assessment in A549 and $\mathrm{H} 1299$ cells

\section{DHPP promoted ROS production}

Treatment of A549 and H1299 cells with DHPP for $24 \mathrm{~h}$ resulted in increases in ROS levels, relative to control cells. The DHPP treatment elevated DCF-fluorescence in A549 and H1299 cells by 7.6 and 6.1 folds, respectively. However, the DHPP-induced increases in DCFfluorescence were effectively suppressed in A549 and H1299 cells pretreated with $10 \mathrm{mM}$ FeTMPyP, an antioxidant.

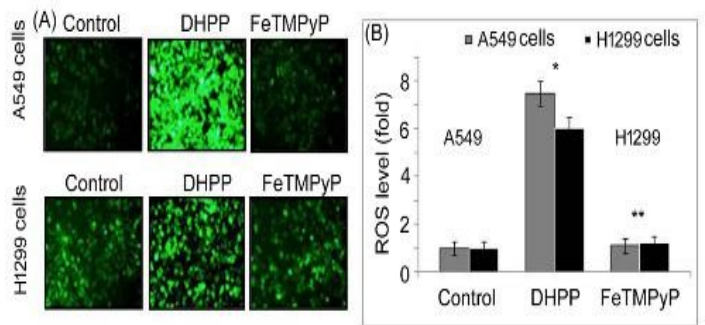

Figure 5: Effect of DHPP on ROS levels in A549 and H1299 cells. (A) ROS levels in DHPP-exposed cells with or without pretreatment with FeTMPyP, as determined using DCF-fluorescence. Fluorescence in cells was captured using Olympus-IX71 microscope. (B) Mean cellular fluorescence intensities (as obtained using Image J software from three different fields). ${ }^{*} p<$ 0.0487 , vs. control cells

\section{FeTMPyP reversed DHPP-induced p38/JNK/ERK-1/2 activation}

Pretreatment with FeTMPyP effectively reversed DHPP-induced increases in p-p38 and p-JNK expressions in A549 and H1299 cells (Figure 6 A). The DHPP-mediated suppression of $p$ ERK1/2 expression was also prevented in A549 and H1299 cells by FeTMPyP pre-treatment. In FeTMPyP-pre-treated A549 and H1299 cells, the DHPP-induced increases in caspase-3 activity were markedly suppressed (Figure $6 \mathrm{~B}$ ).

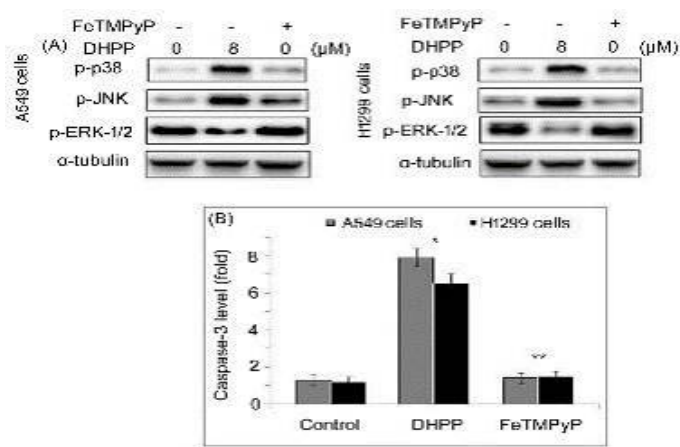

Figure 6: Effect of FeTMPyP on DHPP-induced alterations in $p 38 / J N K / E R K-1 / 2$. (A) p38/JNK/ERK-1/2 expressions in FeTMPyP-pre-treated or untreated A549 and H1299 cells after incubation with DHPP. (B) Caspase-3 levels after $24 \mathrm{~h}$ in FeTMPyP-pre-treated and untreated A549 and H1299 cells after incubation with DHPP. ${ }^{*} p<0.0487$, vs. control cells

\section{DISCUSSION}

The present study demonstrated that DHPP specifically exhibits anti-proliferative effect on A549 and H1299 lung cancer cells without affecting the growth of MRC5 and BEAS-2B (normal cell lines). Oxidative damage and apoptosis were induced in A549 and H1299 cells by DHPP through the MAPK pathway. Various cellular events which regulate diverse processes such as viability, differentiation, death and survival are controlled by MAPK proteins [15]. Activated ERK-1/2 is important in the proliferation of cancer cells, and studies have shown that direct or indirect targeting of ERK-1/2 expression has immense significance for arresting tumor growth $[15,16]$. Activation of stress activated kinase, JNK is linked to different kinds of stress stimuli such as DNA damage, altered cytokine levels, heat shock and exposure to UV radiation [15]. The JNK phosphorylation is most commonly accompanied by simultaneous activation of p38 protein [15]. It is well established that ERK-1/2 activation leads to anti-apoptotic changes and phosphorylation of $\mathrm{p} 38 / \mathrm{JNK}$ has pro-apoptotic effect [17]. 
The present study demonstrated that DHPP treatment promoted p38-phosphorylation in A549 and $\mathrm{H} 1299$ cells. In DHPP-treated A549 and H1299 cells, p-JNK-1/2 expression also showed significant increases. The ERK-1/2 activations in A549 and H1299 cells were markedly downregulated on treatment with DHPP. These findings indicate that DHPP effectively induces pro-apoptotic changes and deactivates antiapoptotic cellular processes. In order to confirm these results, A549 and $\mathrm{H} 1299$ cells were pretreated with PD169316 (p38 inhibitor) or SP600125 (JNK inhibitor) prior to incubation with DHPP. Data showed that DHPP-mediated caspase-3 activation was alleviated in PD169316- or SP600125-pretreated A549 and H1299 cells. Reactive oxygen species are ubiquitous molecules, examples of which are hydrogen peroxide, nitric oxide, hydroxyl radical and singlet oxygen. These ROS influence multiple biological processes. Some crucial steps involved in signal transduction and several other cellular processes are regulated by ROS. Reports have demonstrated that oxidative stress regulates the activation of proteins involved in the MAPK pathway [18]. Abnormal increases in ROS levels are responsible for mitochondrial damage and ultimately results in activation of pro-apoptotic signaling pathway [1921]. In the present study, DHPP treatment of A549 and H1299 cells significantly increased DCFfluorescence, relative to control cells. However, the DHPP-induced increases in DCFfluorescence were effectively suppressed in A549 and H1299 cells on pretreatment with 10 mM FeTMPyP, an antioxidant. Thus, DHPP activated $\mathrm{p} 38 / \mathrm{JNK}$ signaling via oxidative stress which subsequently caused apoptosis of A549 and $\mathrm{H} 1299$ cells.

\section{CONCLUSION}

The results obtained in this study indicate that DHPP selectively targets lung cancer cell growth through oxidative stress which subsequently results in cell apoptosis. Moreover, in lung cancer cells, DHPP treatment activates caspase3 protein and p38/JNK signaling, with simultaneous inactivation of ERK-1/2. Thus, DHPP has inhibitory effect on lung cancer cells, and so possesses some potentials for use in the treatment of lung cancer.

\section{DECLARATIONS}

\section{Conflict of interest}

No conflict of interest is associated with this work.

\section{Contribution of authors}

We declare that this work was done by the author(s) named in this article and all liabilities pertaining to claims relating to the content of this article will be borne by the authors. Zhaohong Chen - conceived and designed the study; Miao $\mathrm{He}$, Chao Li, Yingying $\mathrm{He}$, Guangquan Yang, Youcai Zhang - collected and analyzed the data; Miao $\mathrm{He}$, Chao Li, Yingying $\mathrm{He}$, Guangquan Yang -wrote the manuscript. All authors read and approved the manuscript for publication.

\section{Open Access}

This is an Open Access article that uses a funding model which does not charge readers or their institutions for access and distributed under the terms of the Creative Commons Attribution License (http://creativecommons.org/licenses/by/ 4.0) and the Budapest Open Access Initiative (http://www.budapestopenaccessinitiative.org/rea d), which permit unrestricted use, distribution, and reproduction in any medium, provided the original work is properly credited.

\section{REFERENCES}

1. Jemal A, Siegel R, Ward E, Hao Y, Xu J, Thun MJ. Cancer statistics, 2009. CA Cancer J Clin 2009; 59: 225-249.

2. Larsen JE, Cascone T, Gerber DE, Heymach JV, Minna JD. Targeted therapies for lung cancer: clinical experience and novel agents. Cancer J 2011; 17: 512 527.

3. Hao $Y$, Yang $X$, Zhang $D$, Luo J, Chen $R$. Long noncoding RNA LINC01186, regulated by TGF$\beta / S M A D 3$, inhibits migration and invasion through Epithelial-Mesenchymal-Transition in lung cancer. Gene 2017; 608: 1-12.

4. Schieber M, Chandel NS. ROS function in redox signaling and oxidative stress. Curr Biol 2014; 24: R453-R462.

5. Kamogashira T, Fujimoto C, Yamasoba T. Reactive oxygen species, apoptosis, and mitochondrial dysfunction in hearing loss. BioMed Res Int 2015; 6172072015.

6. Darling NJ, Cook SJ. The role of MAPK signalling pathways in the response to endoplasmic reticulum stress. Biochim Biophys Acta 2014; 1843:2150-2163.

7. Jalmi SK, Sinha AK. ROS mediated MAPK signaling in abiotic and biotic stress- striking similarities and differences. Front Plant Sci 2015; 6: 769.

8. Huang G, Shi LZ, Chi H. Regulation of JNK and p38 MAPK in the immune system: Signal integration, propagation and termination. Cytokine 2009; 48: 161169. 
9. Ouyang L, Shi Z, Zhao S, Wang FT, Zhou TT, Liu B, Bao JK. Programmed cell death pathways in cancer: $A$ review of apoptosis, autophagy and programmed necrosis. Cell Prolif 2012; 45: 487-498.

10. Salama SK, Mohamed MF, Darweesh AF, Elwahy AHM, Abdelhamid IA. Molecular docking simulation and anticancer assessment on human breast carcinoma cell line using novel bis(1,4-dihydropyrano[2,3-c]pyrazole-5carbonitrile) and bis(1,4dihydropyrazolo[4',3':5,6]pyrano[2, 3-b]pyridine-6carbonitrile) derivatives. Bioorg Chem 2017; 71: 19-29.

11. Zaki MEA, Soliman HA, Hiekal OA, Rashad AEZ. Naturforsch C. Pyrazolopyranopyrimidines as a class of anti-Inflammatory agents. J Biosci 2006, 61: 1-5.

12. Huang L-J, Kuo S-C, Wang J-P, Ishii K, Nakamura $H$. Synthesis and antiallergic activities of 2-Alkyl-3, 4dimethylfuro[2, 3-c]pyrazole-5-carboxamides and related compounds. Chem Pharm Bull 1994; 42: 2036-2041.

13. Vichai $V$, Kirtikira $K$. Sulphorhodamine $B$ colorimetric assay for cytotoxicity screening. Nat Protoc 2006; 1(3): 1112-1116.

14. Kalivendi SV, Konorev EA, Cunningham S, Vanamala SK, Kaji EH, Joseph J, Kalyanaraman B. Doxorubicin activates nuclear factor of activated $T$ lymphocytes and Fas ligand transcription: role of mitochondrial reactive oxygen species and calcium. Biochem J. 2005; 389(2): 527-539.
15. Wada T, Penninger JM. Mitogen-activated protein kinases in apoptosis regulation. Oncogene 2004; 23: 2838-2849.

16. Balmanno K, Cook SJ. Tumour cell survival signalling by the ERK 1/2 pathway. Cell Death Differ. 2009; 16(3): 368-77.

17. Xia Z, Dickens M, Raingeaud J, Davis RJ, Greenberg ME. Opposing effects of ERK and JNK-p38 MAP kinases on apoptosis. Science 1995; 270(5240): 13261331.

18. Trachootham $D, L u W$, Ogasawara MA, Nilsa RD, Huang P. Redox regulation of cell survival. Antioxid Redox Signal. 2008; 10(8): 1343-1374.

19. Li J, Yue W, Huang Z, Chen ZQ, Zhan Q, Ren FB, Liu $J Y, F u$ SB. Calcium overload induces C6 rat glioma cell apoptosis in sonodynamic therapy. International journal of radiation biology 2011; 87(10): 1061-1066.

20. Xu ZY, Wang K, Li XQ, Chen S, Deng JM, Cheng Y, Wang ZG. The ABCG2 transporter is a key molecular determinant of the efficacy of sonodynamic therapy with photofrin in glioma stem-like cells. Ultrasonics 2013; 53(1): 232-238.

21. Xiang J, Xia X, Jiang Y, Leung AW, Wang X, Xu J, Wang $P, Y u H$, Bai $D, X u C$. Apoptosis of ovarian cancer cells induced by methylene blue-mediated sonodynamic action. Ultrasonics 2010; 51(3): 390-395. 